\title{
Challenges in the Management of Asthma in the Elderly
}

\author{
Woo-Jung Song, ${ }^{1,2}$ Sang-Heon Cho, ${ }^{1,2 *}$ \\ 'Department of Internal Medicine, Seoul National University College of Medicine, \\ ${ }^{2}$ Institute of Allergy and Clinical Immunology, Seoul National University Medical Research Center, Seoul, Korea
}

This is an Open Access article distributed under the terms of the Creative Commons Attribution Non-Commercial License (http://creativecommons.org/licenses/by-nc/3.0/) which permits unrestricted non-commercial use, distribution, and reproduction in any medium, provided the original work is properly cited.

Recent literature has emphasized the clinical and socio-epidemiological significance of asthma in the elderly. However, why the disease burden remains high in this group is unclear. Elderly subjects usually have multiple chronic illnesses, and the role played by comorbidities in the context of asthma has been underappreciated. This review aims to summarize the literature associations between comorbidities and asthma in elderly patients. In addition, we discuss patient management issues.

Key Words: Asthma; elderly; comorbidity; management

\section{INTRODUCTION}

Asthma in the elderly is a disease of emerging concern. Globally, we are entering an unprecedented era of rapid aging, and the number of elderly people ( $\geq 65$ years of age) is estimated to double by $2030 .{ }^{1}$ In the past, asthma was regarded as mostly a childhood disease. However, recent observations indicate that asthma is associated with a substantial epidemiological burden and a distinct pathophysiology in the elderly; the prevalence and incidence of asthma are higher than expected, and the risk factors more complex. ${ }^{2}$ Socioeconomic costs are also of major concern; elderly patients have disproportionately higher medical demands and poorer outcomes, compared to younger patients. $^{3,4}$

Despite growing literature on the significance of the disease, how to reduce the burden of asthma effectively in the elderly is not clear. ${ }^{2}$ Asthma is likely to be underdiagnosed in the elderly, due to poor perception of symptoms and misattribution to other causes. ${ }^{5,6}$ The level of undertreatment of such asthma was as high as $40 \%$ in $1993,{ }^{7}$ but unexpectedly, it was $33.7 \%$ in $2009 .{ }^{8}$ Moreover, the optimal management of elderly patients with asthma has received little attention, probably because of the complexity of this disease and its being associated with comorbidities and socioeconomic factors. ${ }^{9}$ Elderly subjects can have multiple chronic diseases, ${ }^{10}$ and the number of comorbid conditions (termed the "general comorbidity burden") is significantly associated with poor asthma outcomes. ${ }^{11-13}$ Although comorbidities are accepted to play major roles in elderly patients with asthma, the effects of specific comorbidities may have been underappreciated.

\section{In this review, we aim to summarize the literature on the clini- cal characteristics of elderly patients with asthma, and the asso- ciations between asthma and comorbidities. In addition, we discuss the management issues of asthma and comorbidities in the elderly. \\ Clinical characteristics of asthma in the elderly \\ Asthma in the elderly is a mix of childhood- and adult-onset disease and thus a heterogeneous clinical syndrome. The pro- portion of adult-onset disease among elderly patients is unclear but supposed to be higher than that of childhood-onset dis- ease. ${ }^{14}$ The clinical characteristics of asthma in the elderly are reported to be complex and considerably distinct from the dis- ease in young adults ${ }^{15}$; in particular, a late-onset disease ap- pears to be more severe and less atopic. In our experience with elderly asthma patient cohorts (about 1,000 patients recruited from nine referral hospitals in Korea), more than $90 \%$ reported asthma onset after the age of 50 years, and less than $30 \%$ had atopy. ${ }^{16}$ Despite lower atopic associations, elderly patients have comparable degrees of sputum eosinophils or exhaled nitric oxide levels, compared to younger counterparts. ${ }^{17,18}$ In addition, elderly patients have greater small airway involvements, mea- sured by computed tomography and impulse oscillometry. ${ }^{17}$}

Correspondence to: Sang-Heon Cho, MD, PhD, Department of Internal Medicine, Seoul National University College of Medicine, 101 Daehak-ro, Jongno-gu, Seoul 110-744, Korea.

Tel: +82-2-2072-2971; Fax: +82-2-742-3291; E-mail: shcho@snu.ac.kr Received: January 31, 2015; Accepted: February 23, 2015

- There are no financial or other issues that might lead to conflict of interest. 
Meanwhile, the observed characteristics may vary between studies, depending on definition, sampling methods, or study population. For example, atopic comorbidity was as frequent as $74 \%$ among elderly patients $(n=566$, mean age 71.9 years, mean age of asthma onset 42.3 years) who participated in the Epidemiology and Natural History of Asthma: Outcomes and Treatment Regimens (TENOR) cohort study in the United States. ${ }^{19}$ These findings indicate that further clinical characterization should be based on a large-scale unselected population, and that the mechanistic elucidation using clinical samples should accompany detailed characterization of the study participants.

\section{Epidemiology of asthma in the elderly Prevalence and incidence of asthma in the elderly}

Only a few reports have focused primarily on the prevalence and incidence of asthma in the elderly; prevalence is usually reported as a component of general adult surveys. Therefore, the epidemiological study of asthma in the elderly is still at a rudimentary stage. Cross-sectional surveys have found that the prevalence of asthma is $4.5 \%-12.7 \%$ in the elderly. ${ }^{2}$ Notably, asthma is often more prevalent in the elderly than in younger adults, whether the condition is diagnosed by a self-administered questionnaire alone or a questionnaire together with measures of airway hyperresponsiveness [AHR]). ${ }^{20,21}$ Very few longitudinal surveys have explored asthma incidence in the elderly, although a classical study on residents of Rochester, Minnesota, USA (1964-1983) found that the age- and sex-adjusted incidence of the disease was 95/100,000. ${ }^{22}$ However, a recent French survey of the elderly population, the $3 \mathrm{C}$ cohort study (2000-2004), reported that the incidence of asthma was 3.0/ 1,000 person-years. ${ }^{23}$

\section{Risk factors for asthma in the elderly}

Risk factors for the development of asthma in the elderly remain elusive, because longitudinal studies are very few in number. In the 3C cohort study, abdominal obesity and allergic rhinitis were positively associated with asthma. ${ }^{23}$ In cross-sectional studies, several factors have been associated with current prevalence (usually defined as "the presence of asthma within the past 12 months") in the elderly, including $\mathrm{AHR}^{24}{ }^{24}$ smoking, ${ }^{25}$ rhinitis, ${ }^{26,27}$ or sarcopenic obesity. ${ }^{28}$ Methacholine AHR exhibits a bimodal age distribution in the general population, increasing in the elderly, and may contribute to accelerated lung function decline and the development of asthma in later stages of life. ${ }^{29,30}$ The association between rhinitis and asthma was also observed in nonatopic subjects. ${ }^{26}$ However, to the best of our knowledge, no genetic factor influencing asthma in the elderly has yet been reported, unlike the situation with childhood disease. The prevalence of atopy decreases with aging and is inconsistently associated with asthma in the elderly. ${ }^{2}$ However, IgE-associated asthma in older adults may be attributable to
IgE synthesized after sensitization to staphylococcal enterotoxin (SE). SE-IgE sensitization rates do not appear to decrease with age, but rather increase, and are independently associated with a risk of adult-onset asthma. ${ }^{31,32}$

Such cross-sectional studies have rarely examined the age of asthma onset and afford little information on late-onset asthma in the elderly. Thus, herein, we rely largely on reports on adultonset asthma, and we speculate that the data may be extrapolated to older adults (Fig. 1). The European Community Respiratory Health Survey (ECRHS) is one of the largest population surveys on adult asthma conducted to date, and longitudinal follow-up has revealed that rhinitis is a strong predictor of asthma during adulthood, irrespective of atopic status. ${ }^{33}$ This finding has been supported by another recent European population survey, the Global Allergy and Asthma Network of Excellence (GA ${ }^{2} \mathrm{LEN}$ ) study, which found a strong association between chronic rhinosinusitis (CRS) and adult-onset asthma, irrespective of nasal allergy status. ${ }^{34}$ Regarding this, immune responses to SE may be involved in the relationship ${ }^{31,32}$; Staphylococcus aureus frequently colonizes the human nasal mucosa, and the enterotoxins thereof may provoke CRS and nasal polyp development. ${ }^{35}$ We suppose that SE-IgE is either a biomarker of CRS and asthma, or an active mediator in the relationships between upper and lower airway disease.

Female sex hormone and obesity may be risk factors for adultonset asthma, although the effects of hormonal factors have not been directly examined in the elderly. Upon analysis of ECRHS database information on general adults aged 20-44 years, nonallergic asthma was more prevalent in females than in males during 8-10 years of follow-up, associated with a hazard ratio (HR) of 3.51. ${ }^{36}$ In postmenopausal women (aged 50-70 years) of the E3N cohort, estrogen hormone replacement therapy was positively associated with the risk of de novo asthma develop-

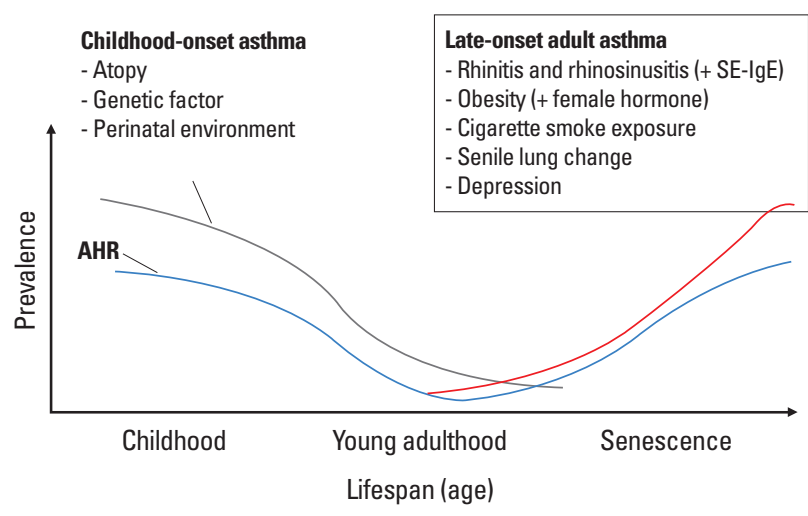

Fig. 1. Schematic presentation for the epidemiology of asthma in the elderly. Lines indicate the aged-related changes in the prevalence; gray line, childhoodonset asthma; blue line, airway hyperresponsiveness; and red line, late-onset adult asthma. Adult asthma prevalence was depicted based on previous publications. ${ }^{25,31}$

AHR, airway hyperresponsiveness; SE-IgE, staphylococcal enterotoxin lgE. 
ment (HR 1.54). ${ }^{37}$ As shown in the 3C study of French elders, ${ }^{23}$ obesity was a risk factor for adult-onset asthma, particularly in females. $^{14,38}$

Smoking is another risk factor, although the reported associations have been somewhat inconsistent in adults. ${ }^{39}$ However, in a recent 16-year follow-up study with a large population cohort $(n=46,182)$, active smoking increased the incidence of adultonset asthma (HR 4.13 for current active smoking and 1.36 for former active smoking). ${ }^{40}$ Among patients with allergic rhinitis, smoking is known to increase the risk of adult-onset asthma in a dose-dependent manner. ${ }^{41}$

The senile change of the lung is another candidate factor for asthma development in the elderly. Aging is associated with reduced elastic recoil and chest wall compliance, ${ }^{42}$ which may enhance AHR in the elderly. ${ }^{29}$ Older age is also associated with accelerated decline in lung function; the estimated rate of decline in forced expiratory volume in 1 second (FEV1) significantly increased with aging (from 12.9 at age 25 to $58.2 \mathrm{~mL} /$ year at age 75$),{ }_{13}^{43}$ which was potentiated by smoking. ${ }^{44}$ In addition, aging is associated with increased amplitude of variability in airway caliber. ${ }^{45,46}$ These findings suggest that the aging process of the lung itself contributes to the development of asthma in the elderly.

\section{Other comorbid conditions}

Several other comorbidities may be potentially important, as elderly subjects have multi-morbidities. In the Korean Longitudinal Study on Health and Aging (KLoSHA) Phase I survey (2005-2006), Korean elders usually had comorbid illnesses in (at least) 3 or 4 organs/systems, defined using the Chronic Illness Rating Scale. ${ }^{10}$ In a recent study conducted in a referral clinic in Poland, elderly patients with asthma had a mean of $8 .{ }^{4}$ chronic comorbid diseases, significantly higher than 3.4 in younger adults. ${ }^{47}$ In a retrospective analysis of the large fourth Korean National Health and Nutrition Survey (KNHANES IV) database, which contains information on 9 major chronic comorbidities, recent wheezing was positively associated with depression (odds ratio $[\mathrm{OR}] 2.08, P<0.001$ ), rhinitis (OR 1.86 , $P=0.035$ ), obesity (OR 1.67, $P=0.024$ ) and arthritis (OR 1.44, $P=0.030) .{ }^{48}$ However, limitations of these studies include case definition and potential type I errors caused by multiple testing, so that more comprehensive studies are required for confirmation.

Depression could be a potential risk factor for asthma in the elderly. A possible psychological aspect of asthma was suggested earlier. ${ }^{49}$ Current epidemiological evidence shows that asthma and depression are frequently comorbid; the most comprehensive cross-sectional study on this topic to date is the World Mental Health Survey conducted in 17 countries involving 85,088 subjects, which found that adults with asthma were at a significantly increased risk of a depressive disorder (OR 1.6). ${ }^{50}$ In the elderly, depression may be particularly important in this context because the observed relationship was independent of other conditions..$^{51}$ The associated mechanisms remain poorly understood. Asthma may impose a significant burden on emotional well-being. Also, the 2 entities have been suggested to share a common pathophysiological pathway. ${ }^{52}$

\section{Comorbid factors associated with poor asthma outcomes in the elderly}

In general, the general comorbidity burden is significantly associated with asthma-related quality of life, ${ }^{53}$ unscheduled asthma care, ${ }^{13}$ emergency department visit, ${ }^{11}$ asthma hospitalization, ${ }^{12}$ or the 30 -day fatality rate following asthma hospitalization. ${ }^{54}$ Here, we briefly describe several comorbid conditions significantly associated with poor asthma outcomes in adults and the elderly (Table 1).

In adults, chronic upper airway disease, particularly sinusitis, is very often associated with poor asthma outcomes. In the Severe Asthma Research Program (SARP), 54\% of patients with severe asthma had a history of sinusitis (vs $33 \%$ of those with mild asthma, and $37 \%$ of those with moderate asthma; $P<$ 0.001). ${ }^{55}$ Later cluster analysis of SARP showed that sinus disease was significantly more frequent in patients with the lateonset asthma phenotype (onset age $\geq 40$ years; cluster 3 ) and the severe asthma phenotype in the oldest subjects (age at en-

Table 1. Summary of comorbid conditions associated with poor asthma outcomes in adults and the elderly

\begin{tabular}{|c|c|}
\hline Comorbid condition & Outcomes of asthma \\
\hline \multirow[t]{5}{*}{ General comorbidity burden } & Impaired asthma-related quality of life ${ }^{53}$ \\
\hline & Unscheduled asthma care ${ }^{13}$ \\
\hline & Emergency department visit ${ }^{11}$ \\
\hline & Frequent hospitalization ${ }^{12}$ \\
\hline & 30-day fatality after asthma hospitalization ${ }^{54}$ \\
\hline \multicolumn{2}{|c|}{ Rhinosinusitis and/or nasal polyp Severity ${ }^{55-57}$} \\
\hline SE-lgE sensitization & Severity ${ }^{58}$ \\
\hline \multirow[t]{3}{*}{ Obesity } & Symptom frequency and activity ${ }^{28,60}$ \\
\hline & Asthma-related costs ${ }^{64}$ \\
\hline & Severity (controversial) ${ }^{57,61}$ \\
\hline \multirow[t]{6}{*}{ Smoking } & Asthma-related quality of life ${ }^{66}$ \\
\hline & Poor asthma control ${ }^{66}$ \\
\hline & Frequent exacerbation ${ }^{16,66}$ \\
\hline & Frequent hospitalization ${ }^{66}$ \\
\hline & Asthma-related mortality ${ }^{66}$ \\
\hline & Fixed airway obstruction ${ }^{66,67}$ \\
\hline \multirow[t]{2}{*}{ COPD overlap, or reduced FEV1 } & Poor asthma control ${ }^{70}$ \\
\hline & Frequent exacerbation ${ }^{16}$ \\
\hline \multirow[t]{2}{*}{ Depression } & Poor medication adherence ${ }^{72}$ \\
\hline & Frequent exacerbation ${ }^{73}$ \\
\hline
\end{tabular}

SE-lgE, staphylococcal enterotoxin IgE; COPD, chronic obstructive pulmonary disease; FEV1, forced expiratory volume in 1 second. 
rolment 50 years; cluster 3 and 5) compared to those with earlyonset asthma phenotypes. ${ }^{56}$ In Europe, the risk factors for asthma severity have been examined particularly in patients with adult-onset asthma; nasal polyposis exhibits a strong association with asthma (OR 3.2). ${ }^{57}$ Although very few studies have been conducted in elderly patients, we recently observed that comorbid CRS is an independent risk factor for frequent asthma exacerbation and disease severity in the elderly (Song, Cho et al., Staphylococcal enterotoxin IgE sensitization in late-onset severe eosinophilic asthma in the elderly; manuscript submitted). Also, SE-IgE sensitization is independently associated with poor outcomes and asthma severity in nonatopic adult patients, ${ }^{58}$ and with severe eosinophilic asthma in the elderly (Song, Cho et al., manuscript submitted). Notably, atopy was not associated with asthma severity in the cited studies. ${ }^{58}$

Obesity has been associated with poor asthma outcomes including a high frequency of symptoms and corticosteroid insensitivity, ${ }^{59,60}$ but may not be directly related to asthma severity. Cluster analyses performed in the United States and Europe have repeatedly identified obese patients as exhibiting a distinct asthma phenotype, ${ }^{56,60,61}$ although obesity-related phenotypes are sometimes heterogeneous (not being confined to severe disease) ${ }^{61}$ Later studies also found that obesity is not associated with asthma severity in adult-onset patients. ${ }^{57}$ Nevertheless, these findings do not confirm that obesity is not a risk factor, because weight loss interventions improved asthma control-related outcomes in a group of obese patients. ${ }^{62}$ Thus, obesity may modify asthma, rendering the disease more difficult to treat, presumably by modulating treatment responsiveness, adipokine levels, or innate immune responses. ${ }^{63}$ In the elderly, comorbid obesity is related to the risk of recent wheezing and higher asthma-related costs. ${ }^{28,64}$

Smoking is a well-known risk factor for various health conditions, including asthma. A considerable proportion of adult patients with asthma have a smoking history, recently characterized as the "smoking asthma" phenotype. ${ }^{65}$ Several mechanisms have been suggested to explain the adverse consequences of smoking on asthma. ${ }^{66}$ Clinically, smoking is related to virtually every aspect of asthma control, including poor asthmarelated quality of life, poor asthma control, more frequent exacerbation, hospitalization, and asthma-related mortality. Smoking also significantly worsens lung function parameters, leading to persistent airway obstruction and the development of the asthma-chronic obstructive pulmonary disease (COPD) overlap phenotype. ${ }^{66,67}$

The prevalence of COPD overlap may depend on the definition and study population, but increases with aging, and is reported as frequent as $30 \%$ among elderly patients with asthma. ${ }^{68-70}$ Such patients are at higher risk of poor asthma control, and more frequent exacerbation (prevalence ratio [PR] 2.11) and hospitalization (PR 4.11) than the elderly asthma-alone or COPD-alone groups. ${ }^{70,71}$ In our experience, a smoking history
( $\geq 31.5$ pack-years) and reduced lung function (postbronchodilator FEV1 <61.1\%) are 2 major factors predicting the risk of future asthma exacerbation in the elderly. ${ }^{16}$

Depression is a risk factor for poor asthma control and deserves more attention. Depressive symptoms are common among adult patients with active asthma and also associated with poor adherence to asthma therapy after hospital discharge. ${ }^{72}$ The impact of depression on asthma in the elderly has also been demonstrated in prospective cohort studies; depression is associated with a higher risk of poor medication adherence and poor asthma outcomes, including more exacerbations. ${ }^{73,74}$ Moreover, comorbid depression is significantly associated with a higher 5-year mortality rate among elderly patients with asthma. ${ }^{75}$

Several other comorbid conditions may potentially impact asthma in the elderly; these include gastroesophageal reflux disease, aspirin sensitivity, cardiac dysfunction, a history of pulmonary tuberculosis, vocal cord dysfunction, and obstructive sleep apnea. We, however, do not discuss these conditions here. ${ }^{76-78}$

\section{Management of comorbidities}

Despite the effects of multiple comorbidities on asthma, no study has directly examined the effects of comorbidity control on asthma outcomes in the elderly. The lack of clinical trials may reflect the fact that the elderly have multiple comorbidities that could confound trial outcomes. We searched the Pubmed database using the query (randomized AND trial AND asthma AND ["older adults" OR "elderly"] [access date: 2015/Jan/12]) and obtained very few results. Thus, we herein refer to the clinical data from adult patients in general (Table 2).

First, treatment of comorbid upper airway diseases may be potentially beneficial, but intranasal corticosteroid pharmacotherapy alone may not be sufficient to improve asthma control. In a previous meta-analysis, compared to a placebo intranasal corticosteroids improved FEV1 and some asthma-specific outcomes in patients with asthma who had comorbid allergic rhinitis. However, the effects were significant only in patients who were not on inhaled or oral corticosteroid therapy ${ }^{79}$ In a recent elegant controlled trial, a 24-week course of nasal mometasone given to treat chronic sinonasal disease in patients with inadequately controlled asthma did not significantly improve asthma control..$^{80}$ In a meta-analysis of the role played by sinus surgery among patients with asthma having comorbid CRS, such surgery had positive effects on the clinical outcomes of asthma, ${ }^{81}$ although controlled trials are lacking. In a clinical trial of patients with nasal polyps and comorbid asthma, a 16-week course of omalizumab improved both polyp scores and asthma symptoms, suggesting the importance of controlling local IgE which is driven by SE. ${ }^{82}$

Second, weight loss interventions may impact asthma. In an open-label, randomized, controlled trial of a 1-year supervised 
Table 2. Summary of major clinical trials on the effects of controlling comorbidity on asthma outcomes in adults

\begin{tabular}{|c|c|c|c|}
\hline First author (year) ${ }^{\text {ref }}$ & Participants & Study design and intervention & Main findings on the intervention \\
\hline Dixon $(2014)^{80}$ & $\begin{array}{l}237 \text { adults and } 151 \text { children with chronic } \\
\text { sinonasal disease and inadequately } \\
\text { controlled asthma (median age } 27 \text { years } \\
\text { old) }\end{array}$ & $\begin{array}{l}\text { 24-week randomized double-blind } \\
\text { placebo-controlled trial, intranasal } \\
\text { mometasone versus placebo }\end{array}$ & $\begin{array}{l}\text { In adults, there was a small difference in } \\
\text { asthma symptoms and in nasal symptoms, } \\
\text { but no difference in asthma quality of life, } \\
\text { lung function, or episodes of poorly } \\
\text { controlled asthma. }\end{array}$ \\
\hline Gevaert $(2012)^{82}$ & $\begin{array}{l}24 \text { patients with nasal polyps and asthma } \\
\text { (median age around } 50 \text { years old) }\end{array}$ & $\begin{array}{l}\text { 16-week randomized double-blind } \\
\text { placebo-controlled trial, omalizumab } \\
\text { versus placebo }\end{array}$ & $\begin{array}{l}\text { There was a significant decrease in } \\
\text { endoscopic polyp scores and Lund-Mackay } \\
\text { score, and also in upper and lower airway } \\
\text { symptoms and quality of life scores. }\end{array}$ \\
\hline Stenius-Aarniala $(2000)^{83}$ & $\begin{array}{l}38 \text { patients with asthma and obesity } \\
\text { (BMI } 30-42 \mathrm{~kg} / \mathrm{m}^{2} \text {, age } 18-60 \text { years old) }\end{array}$ & $\begin{array}{l}\text { 1-year randomized open-labelled } \\
\text { controlled trial, supervised weight } \\
\text { reduction program with 8-week very } \\
\text { low energy diet versus standard care }\end{array}$ & $\begin{array}{l}\text { There were significant reduction in body } \\
\text { weight (14.5\%) and also improvements in } \\
\text { lung function parameters (FEV1 and FVC), } \\
\text { dyspnea scale, rescue medication use, and } \\
\text { exacerbation frequency. }\end{array}$ \\
\hline Dias-Júnior (2014) $)^{84}$ & $\begin{array}{l}33 \text { patients with severe asthma and obesity } \\
\text { (mean BMI } 39 \mathrm{~kg} / \mathrm{m}^{2} \text {, mean age } 42 \text { years } \\
\text { old) }\end{array}$ & $\begin{array}{l}\text { 6-month randomized open-labelled } \\
\text { controlled trial, weight loss program } \\
\text { (low caloric intake, sibutramine } 10 \mathrm{mg} \text { per } \\
\text { day, and orlistat maximum } 120 \mathrm{mg} \text { per day) } \\
\text { versus standard care }\end{array}$ & $\begin{array}{l}\text { There were significant reduction in body } \\
\text { weight (7.5\%) and also improvements in } \\
\text { asthma control and FVC. }\end{array}$ \\
\hline Chaudhuri (2006) ${ }^{85}$ & $\begin{array}{l}32 \text { smokers with asthma (mean age } 47 \\
\text { years old, } 36 \text { pack-year) }\end{array}$ & $\begin{array}{l}\text { 6-week, non-randomized open controlled } \\
\text { trial, smoking cessation }\end{array}$ & $\begin{array}{l}\text { There were significant improvement in FEV1 } \\
\text { and reduction in sputum neutrophils. }\end{array}$ \\
\hline Tønnesen $(2005)^{86}$ & $\begin{array}{l}220 \text { smokers with asthma (mean age } 35 \\
\text { years old, } 19 \text { pack-year) }\end{array}$ & $\begin{array}{l}\text { 4-month, randomized open controlled trial, } \\
\text { complete smoking cessation versus } \\
\text { smoking reduction to fewer than seven } \\
\text { cigarettes/day versus continuation of } \\
\text { usual smoking }\end{array}$ & $\begin{array}{l}\text { There were significant improvements in } \\
\text { asthma-specific quality of life score, } \\
\text { reductions in self-reported day and night } \\
\text { use of rescue } \beta 2 \text {-agonists, doses of } \\
\text { inhaled corticosteroids, in daytime asthma } \\
\text { symptoms, and in bronchial hyperreactivity. }\end{array}$ \\
\hline
\end{tabular}

BMI, body mass index; FEV1, forced expiratory volume in 1 second; FVC, forced vital capacity.

weight reduction program vs standard care in 38 obese patients with asthma (age 18-60 years; body mass index [BMI] $30-42 \mathrm{~kg} /$ $\mathrm{m}^{2}$ ), the weight reduction program afforded a mean weight loss of $14.5 \%$ and improved several asthma outcomes, including lung function, dyspnea score, and the need for rescue medication. ${ }^{83}$ In obese patients with severe asthma (mean age 42 years; BMI $39 \mathrm{~kg} / \mathrm{m}^{2}$ ), a 6-month weight reduction intervention (achieving a mean reduction in weight of 7.5\%) improved asthma control and 1 lung function parameter (forced vital capacity). ${ }^{84}$ These findings provide clinical evidence that weight loss intervention is a potential treatment option in certain patients.

Third, smoking cessation may improve asthma outcomes. In short, complete cessation of smoking for 6 weeks significantly improved the FEV1 (by a mean of $407 \mathrm{~mL}$ ) and decreased the mean sputum neutrophil percentage (by 29\%) in middle-aged adults. ${ }^{85}$ In a larger randomized trial with 220 patients, a 4-month smoking cessation improved several asthma outcomes in a dose-dependent manner, including the asthmaspecific quality of life, the use of $\beta 2$-agonist rescue therapy, inhaled corticosteroid (ICS) dose, daytime asthma symptoms, and AHR. ${ }^{86}$ However, multidisciplinary approaches combining counseling with medical therapy are necessary. ${ }^{66}$
Finally, despite the frequently reported association of asthma with depression, the literature on the efficacy of depression control on the asthma outcomes of patients of any age is very sparse. In contrast, however, reports on a link between depression and COPD are growing in number. ${ }^{87}$ In terms of psychological interventions in general, 1 meta-analysis found that cognitive behavioral therapy improves the asthma-related quality of life and that relaxation therapy reduces the use of asthma medication. However, drawing firm conclusions was not possible because of insufficient patient numbers and heterogeneity in study design. ${ }^{88}$

\section{Other management issues in the elderly}

Some practical issues are particularly important in the elderly. In a Korean study on an elderly asthma cohort, poor adherence to ICS therapy and the absence of a caregiver were significant risk factors for exacerbations. ${ }^{73}$ In an 8-week pilot study on very old patients (mean age 81.6 years) with poorly controlled asthma and comorbidities in Japan, assistance by caregivers when using ICS therapy effectively improved the lung function. ${ }^{89}$ However, the usual asthma education strategy, which deals only with how to use a peak flowmeter and follow an asthma 
action plan, failed to improve asthma outcomes in the elderly. ${ }^{90}$ Thus, adherence is a complex issue in the elderly.

A recent series of studies conducted by Federman et al. in the United States has afforded some novel insights into the management of elderly patients. In an Asthma Beliefs and Literacy in the Elderly (ABLE) cohort, 57.0\% of the elderly patients with asthma exhibited poor adherence to daily asthma controller medications. ${ }^{91}$ This was significantly associated with erroneous beliefs about asthma and treatment thereof, particularly a "no symptoms, no asthma" belief (58.7\% of the poorly adherent group). Notably, inaccurate beliefs, poor adherence, and the use of incorrect inhaler techniques are more frequent among patients with low levels of health literacy. ${ }^{92-94}$ This term means "the degree to which individuals have the capacity to obtain, process and understand basic health information and services to make appropriate health decisions." ${ }^{92}$ Moreover, reduced cognitive function was associated with poor medication behaviors and explained the literacy problem, at least in part. ${ }^{94}$ Thus, interventions for the elderly must be tailored to the individual levels of health literacy and cognitive function.

Use of an individualized approach is supported by a recent controlled intervention study, which investigated the efficacy of individualized self-regulation program intervention on asthma outcomes in the elderly. ${ }^{95}$ In this program, patients are assisted by a health educator to identify personal asthma-related problems/barriers and to develop plans to achieve asthma-specific goals. The intervention runs for 6 weeks, and effectively improves asthma-related quality of life, asthma control, and unscheduled health care utilization. The effects are maintained for about 1 year.

Continuity of care is another important issue in the elderly. In an analysis of the Korea National Health Insurance Claims database, a higher level of continuity of care was significantly associated with a lower risk of hospitalization of and reduced medical costs for elderly persons with asthma. ${ }^{96}$ Collectively, these findings indicate that multidisciplinary approaches are needed to manage asthma in the elderly.

The general rules of pharmacotherapy for the elderly are not different from those for general adult patients. However, the treatment response needs to be carefully monitored because elderly patients may have discordant correlations between changes in symptoms and lung function. ${ }^{97}$ In addition, side effects, polypharmacy, and drug interactions are major concerns in the elderly. ${ }^{2}$ Concomitant oral corticosteroids may increase the risk of hypothalamic-pituitary-adrenal axis suppression in elderly patients on long-term ICS therapy, ${ }^{98}$ and inhaled $\beta$-agonists may induce tremor or tachycardia in susceptible patients. Inhaled long-acting anticholinergics may be a good option if bronchodilating and possible anti-inflammatory effects are sought, ${ }^{99}$ considering the age-related reduction in lung function and the frequent overlap between asthma and COPD in the elderly. ${ }^{68-70}$ Theophylline levels must be monitored regularly, and possible

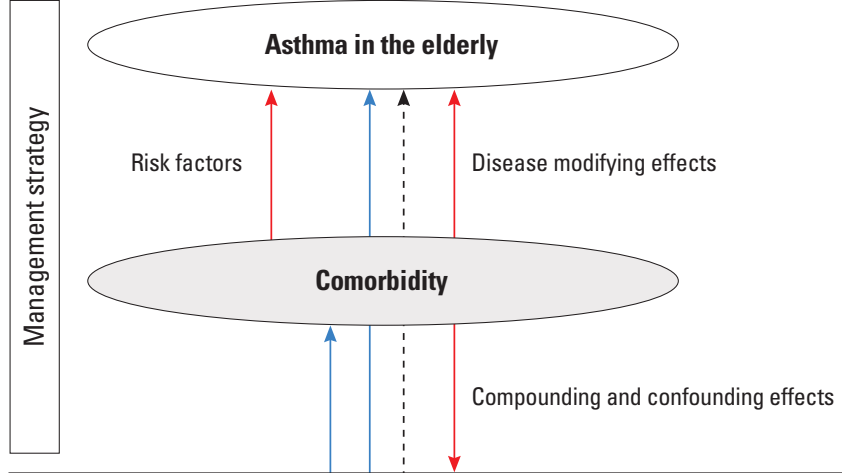

Other management issues:

Adherence / Health literacy / Cognitive function / Self-management / Pharmacotherapy

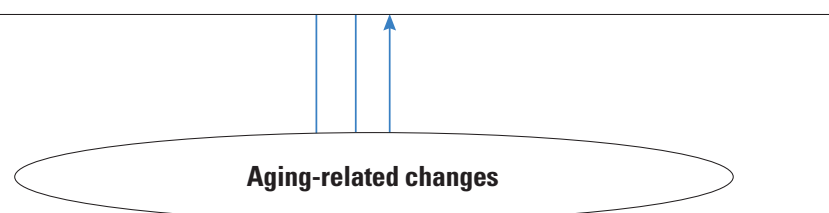

Fig. 2. Management issues of asthma in the elderly. Arrows with lines indicate the hypothetical relationships between aging, asthma, comorbidity, and other issues. Red line, effects of comorbidity; blue line, effects of aging-related changes; and dotted black line, effects of other management issues.

drug interactions (upon concomitant treatment) must be carefully considered. ${ }^{2}$ Leukotriene receptor antagonists are usually well-tolerated, but the efficacy thereof in the elderly warrants further investigation. ${ }^{100}$

\section{CONCLUSIONS}

Many challenges in management of asthma in the elderly are apparent. Not only asthma management issues, but also comorbid conditions impose significant burdens on the elderly (Fig. 2). Despite the significance of comorbidities, very little clinical evidence is available on the efficacy of controlling comorbidities in the elderly; previous trials have rarely focused on elderly patients. Several other practical issues must be considered, including the role of a caregiver, health literacy, and cognitive functioning. Thus, management of asthma in the elderly should be multifaceted, and the recent growth in reports on elderly health is encouraging. We anticipate that an evidencebased management strategy for asthma and multiple comorbidities in the elderly will be forthcoming.

\section{ACKNOWLEDGMENTS}

The research was supported by the grant (2008-E33028-00, 2009-E33022-00, 2011-E33005-00, 2012-E33004-00, 2013E33009-00) of the Ministry of Health and Welfare, Republic of Korea. 


\section{REFERENCES}

1. Kinsella K, He W. An aging world: 2008. International Population Reports. Washington, D.C.: U.S. Government Printing Office; 2009.

2. Yáñez A, Cho SH, Soriano JB, Rosenwasser LJ, Rodrigo GJ, Rabe KF, et al. Asthma in the elderly: what we know and what we have yet to know. World Allergy Organ J 2014;7:8.

3. Tsai CL, Lee WY, Hanania NA, Camargo CA Jr. Age-related differences in clinical outcomes for acute asthma in the United States, 2006-2008. J Allergy Clin Immunol 2012;129:1252-1258.e1.

4. Bahadori K, Doyle-Waters MM, Marra C, Lynd L, Alasaly K, Swiston J, et al. Economic burden of asthma: a systematic review. BMC Pulm Med 2009;9:24.

5. Parameswaran K, Hildreth AJ, Chadha D, Keaney NP, Taylor IK, Bansal SK. Asthma in the elderly: underperceived, underdiagnosed and undertreated; a community survey. Respir Med 1998; 92:573-7.

6. Bellia V, Battaglia S, Catalano F, Scichilone N, Incalzi RA, Imperiale $\mathrm{C}$, et al. Aging and disability affect misdiagnosis of COPD in elderly asthmatics: the SARA study. Chest 2003;123:1066-72.

7. Enright PL, Kronmal RA, Higgins MW, Schenker MB, Haponik EF. Prevalence and correlates of respiratory symptoms and disease in the elderly. Cardiovascular Health Study. Chest 1994;106:827-34.

8. Lee JA, P LR, Berg JP. Asthma characteristics among older adults: using the California health interview survey to examine asthma incidence, morbidity and ethnic differences. J Asthma 2014;51:399404.

9. Gillman A, Douglass JA. Asthma in the elderly. Asia Pac Allergy 2012;2:101-8.

10. Song WJ, Morice AH, Kim MH, Lee SE, Jo EJ, Lee SM, et al. Cough in the elderly population: relationships with multiple comorbidity. PLoS One 2013;8:e78081.

11. Patel MR, Janevic MR, Heeringa SG, Baptist AP, Clark NM. An examination of adverse asthma outcomes in U.S. Adults with multiple morbidities. Ann Am Thorac Soc 2013;10:426-31.

12. Aubas C, Bourdin A, Aubas P, Gamez AS, Halimi L, Vachier I, et al. Role of comorbid conditions in asthma hospitalizations in the south of France. Allergy 2013;68:637-43.

13. Steppuhn H, Langen U, Keil T, Scheidt-Nave C. Chronic disease comorbidity of asthma and unscheduled asthma care among adults: results of the national telephone health interview survey German Health Update (GEDA) 2009 and 2010. Prim Care Respir J 2014; 23:22-9.

14. Sood A, Qualls C, Schuyler M, Arynchyn A, Alvarado JH, Smith LJ, et al. Adult-onset asthma becomes the dominant phenotype among women by age 40 years. The longitudinal CARDIA study. Ann Am Thorac Soc 2013;10:188-97.

15. Park HW, Kwon HS, Kim TB, Kim SH, Chang YS, Jang AS, et al. Differences between asthma in young and elderly: results from the COREA study. Respir Med 2013;107:1509-14.

16. Park HW, Song WJ, Kim SH, Park HK, Kim SH, Kwon YE, et al. Classification and implementation of asthma phenotypes in elderly patients. Ann Allergy Asthma Immunol 2015;114:18-22.

17. Inoue H, Niimi A, Takeda T, Matsumoto H, Ito I, Matsuoka H, et al. Pathophysiological characteristics of asthma in the elderly: a comprehensive study. Ann Allergy Asthma Immunol 2014;113:527-33.

18. Ducharme ME, Prince P, Hassan N, Nair P, Boulet LP. Expiratory flows and airway inflammation in elderly asthmatic patients. Respir Med 2011;105:1284-9.
19. Slavin RG, Haselkorn T, Lee JH, Zheng B, Deniz Y, Wenzel SE, et al. Asthma in older adults: observations from the epidemiology and natural history of asthma: outcomes and treatment regimens (TENOR) study. Ann Allergy Asthma Immunol 2006;96:406-14.

20. Kim S, Kim J, Kim K, Kim Y, Park Y, Baek S, et al. Healthcare use and prescription patterns associated with adult asthma in Korea: analysis of the NHI claims database. Allergy 2013;68:1435-42.

21. Song WJ, Kang MG, Chang YS, Cho SH. Epidemiology of adult asthma in Asia: toward a better understanding. Asia Pac Allergy 2014;4: 75-85.

22. Bauer BA, Reed CE, Yunginger JW, Wollan PC, Silverstein MD. Incidence and outcomes of asthma in the elderly. A population-based study in Rochester, Minnesota. Chest 1997;111:303-10.

23. Leone N, Courbon D, Berr C, Barberger-Gateau P, Tzourio C, Alpérovitch $\mathrm{A}$, et al. Abdominal obesity and late-onset asthma: crosssectional and longitudinal results: the $3 \mathrm{C}$ study. Obesity (Silver Spring) 2012;20:628-35.

24. Choy DK, Hui DS, Li ST, Ko FW, Ho S, Woo J, et al. Prevalence of wheeze, bronchial hyper-responsiveness and asthma in the elderly Chinese. Clin Exp Allergy 2002;32:702-7.

25. Kim YK, Kim SH, Tak YJ, Jee YK, Lee BJ, Kim SH, et al. High prevalence of current asthma and active smoking effect among the elderly. Clin Exp Allergy 2002;32:1706-12.

26. Song WJ, Kim MY, Jo EJ, Kim MH, Kim TH, Kim SH, et al. Rhinitis in a community elderly population: relationships with age, atopy, and asthma. Ann Allergy Asthma Immunol 2013;111:347-51.

27. Pite H, Pereira AM, Morais-Almeida M, Nunes C, Bousquet J, Fonseca JA. Prevalence of asthma and its association with rhinitis in the elderly. Respir Med 2014;108:1117-26.

28. Song WJ, Kim SH, Lim S, Park YJ, Kim MH, Lee SM, et al. Association between obesity and asthma in the elderly population: potential roles of abdominal subcutaneous adiposity and sarcopenia. Ann Allergy Asthma Immunol 2012;109:243-8.

29. Hopp RJ, Bewtra A, Nair NM, Townley RG. The effect of age on methacholine response. J Allergy Clin Immunol 1985;76:609-13.

30. O'Connor GT, Sparrow D, Weiss ST. A prospective longitudinal study of methacholine airway responsiveness as a predictor of pulmonary-function decline: the Normative Aging Study. Am J Respir Crit Care Med 1995;152:87-92.

31. Song WJ, Chang YS, Lim MK, Yun EH, Kim SH, Kang HR, et al. Staphylococcal enterotoxin sensitization in a community-based population: a potential role in adult-onset asthma. Clin Exp Allergy 2014;44:553-62.

32. Tomassen P, Jarvis D, Newson R, Van Ree R, Forsberg B, Howarth P, et al. Staphylococcus aureus enterotoxin-specific IgE is associated with asthma in the general population: a GA(2)LEN study. Allergy 2013;68:1289-97.

33. Shaaban R, Zureik M, Soussan D, Neukirch C, Heinrich J, Sunyer J, et al. Rhinitis and onset of asthma: a longitudinal populationbased study. Lancet 2008;372:1049-57.

34. Jarvis D, Newson R, Lotvall J, Hastan D, Tomassen P, Keil T, et al. Asthma in adults and its association with chronic rhinosinusitis: the GA2LEN survey in Europe. Allergy 2012;67:91-8.

35. Song WJ, Jo EJ, Lee JW, Kang HR, Cho SH, Min KU, et al. Staphylococcal enterotoxin specific IgE and asthma: a systematic review and meta-analysis. Asia Pac Allergy 2013;3:120-6.

36. Leynaert B, Sunyer J, Garcia-Esteban R, Svanes C, Jarvis D, Cerveri I, et al. Gender differences in prevalence, diagnosis and incidence of allergic and non-allergic asthma: a population-based cohort. Tho- 
$\operatorname{rax} 2012 ; 67: 625-31$.

37. Romieu I, Fabre A, Fournier A, Kauffmann F, Varraso R, Mesrine S, et al. Postmenopausal hormone therapy and asthma onset in the E3N cohort. Thorax 2010;65:292-7.

38. Beuther DA, Sutherland ER. Overweight, obesity, and incident asthma: a meta-analysis of prospective epidemiologic studies. Am J Respir Crit Care Med 2007;175:661-6.

39. McLeish AC, Zvolensky MJ. Asthma and cigarette smoking: a review of the empirical literature. J Asthma 2010;47:345-61.

40. Coogan PF, Castro-Webb N, Yu J, O'Connor GT, Palmer JR, Rosenberg L. Active and passive smoking and the incidence of asthma in the Black Women's Health Study. Am J Respir Crit Care Med 2015; 191:168-76.

41. Polosa R, Knoke JD, Russo C, Piccillo G, Caponnetto P, Sarvà M, et al. Cigarette smoking is associated with a greater risk of incident asthma in allergic rhinitis. J Allergy Clin Immunol 2008;121:1428-34.

42. Verbeken EK, Cauberghs M, Mertens I, Clement J, Lauweryns JM, Van de Woestijne KP. The senile lung. Comparison with normal and emphysematous lungs. 2. Functional aspects. Chest 1992;101: 800-9.

43. Ware JH, Dockery DW, Louis TA, Xu XP, Ferris BG Jr, Speizer FE. Longitudinal and cross-sectional estimates of pulmonary function decline in never-smoking adults. Am J Epidemiol 1990;132:685700 .

44. James AL, Palmer LJ, Kicic E, Maxwell PS, Lagan SE, Ryan GF, et al. Decline in lung function in the Busselton Health Study: the effects of asthma and cigarette smoking. Am J Respir Crit Care Med 2005; 171:109-14.

45. Enright PL, Burchette RJ, Peters JA, Lebowitz MD, McDonnell WF, Abbey DE. Peak flow lability: association with asthma and spirometry in an older cohort. Chest 1997;112:895-901.

46. Bellia V, Cuttitta G, Cibella F, Vignola AM, Crescimanno G, D’Accardi $\mathrm{P}$, et al. Effect of ageing on peak expiratory flow variability and nocturnal exacerbations in bronchial asthma. Eur Respir J 1997;10: 1803-8.

47. Wardzyńska A, Kubsik B, Kowalski ML. Comorbidities in elderly patients with asthma: association with control of the disease and concomitant treatment. Geriatr Gerontol Int. Forthcoming 2014.

48. Park J, Kim TB, Joo H, Lee JS, Lee SD, Oh YM. Diseases concomitant with asthma in middle-aged and elderly subjects in Korea: a population-based study. Allergy Asthma Immunol Res 2013;5:16-25.

49. Di Marco F, Santus P, Centanni S. Anxiety and depression in asthma. Curr Opin Pulm Med 2011;17:39-44.

50. Scott KM, Von Korff M, Ormel J, Zhang MY, Bruffaerts R, Alonso J, et al. Mental disorders among adults with asthma: results from the World Mental Health Survey. Gen Hosp Psychiatry 2007;29:123-33.

51. Niti M, Ng TP, Kua EH, Ho RC, Tan CH. Depression and chronic medical illnesses in Asian older adults: the role of subjective health and functional status. Int J Geriatr Psychiatry 2007;22:1087-94.

52. Jiang M, Qin P, Yang X. Comorbidity between depression and asthma via immune-inflammatory pathways: a meta-analysis. J Affect Disord 2014;166:22-9.

53. Adams RJ, Wilson DH, Taylor AW, Daly A, Tursan d'Espaignet E, Dal Grande E, et al. Coexistent chronic conditions and asthma quality of life: a population-based study. Chest 2006;129:285-91.

54. Roberts NJ, Lewsey JD, Gillies M, Briggs AH, Belozeroff V, Globe DR, et al. Time trends in 30 day case-fatality following hospitalisation for asthma in adults in Scotland: a retrospective cohort study from 1981 to 2009. Respir Med 2013;107:1172-7.
55. Moore WC, Bleecker ER, Curran-Everett D, Erzurum SC, Ameredes BT, Bacharier L, et al. Characterization of the severe asthma phenotype by the National Heart, Lung, and Blood Institute's Severe Asthma Research Program. J Allergy Clin Immunol 2007;119:405-13.

56. Moore WC, Meyers DA, Wenzel SE, Teague WG, Li H, Li X, et al. Identification of asthma phenotypes using cluster analysis in the Severe Asthma Research Program. Am J Respir Crit Care Med 2010; 181:315-23.

57. Amelink M, de Groot JC, de Nijs SB, Lutter R, Zwinderman AH, Sterk PJ, et al. Severe adult-onset asthma: A distinct phenotype. J Allergy Clin Immunol 2013;132:336-41.

58. Bachert C, van Steen K, Zhang N, Holtappels G, Cattaert T, Maus B, et al. Specific IgE against Staphylococcus aureus enterotoxins: an independent risk factor for asthma. J Allergy Clin Immunol 2012; 130:376-381.e8.

59. Sutherland ER, Goleva E, Strand M, Beuther DA, Leung DY. Body mass and glucocorticoid response in asthma. Am J Respir Crit Care Med 2008;178:682-7.

60. Haldar P, Pavord ID, Shaw DE, Berry MA, Thomas M, Brightling CE, et al. Cluster analysis and clinical asthma phenotypes. Am J Respir Crit Care Med 2008;178:218-24.

61. Sutherland ER, Goleva E, King TS, Lehman E, Stevens AD, Jackson LP, et al. Cluster analysis of obesity and asthma phenotypes. PLoS One 2012;7:e36631.

62. Moreira A, Bonini M, Garcia-Larsen V, Bonini S, Del Giacco SR, Agache I, et al. Weight loss interventions in asthma: EAACI evidence-based clinical practice guideline (part I). Allergy 2013;68:42539.

63. Kim SH, Sutherland ER, Gelfand EW. Is there a link between obesity and asthma? Allergy Asthma Immunol Res 2014;6:189-95.

64. Shah R, Yang Y. Health and economic burden of obesity in elderly individuals with asthma in the United States. Popul Health Manag. Forthcoming 2014.

65. Kim TB, Jang AS, Kwon HS, Park JS, Chang YS, Cho SH, et al. Identification of asthma clusters in two independent Korean adult asthma cohorts. Eur Respir J 2013;41:1308-14.

66. Polosa R, Thomson NC. Smoking and asthma: dangerous liaisons. Eur Respir J 2013;41:716-26.

67. de Marco R, Pesce G, Marcon A, Accordini S, Antonicelli L, Bugiani $\mathrm{M}$, et al. The coexistence of asthma and chronic obstructive pulmonary disease (COPD): prevalence and risk factors in young, middle-aged and elderly people from the general population. PLoS One 2013;8:e62985.

68. Zeki AA, Schivo M, Chan A, Albertson TE, Louie S. The asthmaCOPD overlap syndrome: a common clinical problem in the elderly. J Allergy (Cairo) 2011;2011:861926.

69. Soriano JB, Davis KJ, Coleman B, Visick G, Mannino D, Pride NB. The proportional Venn diagram of obstructive lung disease: two approximations from the United States and the United Kingdom. Chest 2003;124:474-81.

70. Milanese M, Di Marco F, Corsico AG, Rolla G, Sposato B, Chieco-Bianchi F, et al. Asthma control in elderly asthmatics. An Italian observational study. Respir Med 2014;108:1091-9.

71. Menezes AM, Montes de Oca M, Pérez-Padilla R, Nadeau G, Wehrmeister FC, Lopez-Varela MV, et al. Increased risk of exacerbation and hospitalization in subjects with an overlap phenotype: COPDasthma. Chest 2014;145:297-304.

72. Smith A, Krishnan JA, Bilderback A, Riekert KA, Rand CS, Bartlett SJ. Depressive symptoms and adherence to asthma therapy after 
hospital discharge. Chest 2006;130:1034-8.

73. Park HW, Kim TW, Song WJ, Kim SH, Park HK, Kim SH, et al. Prediction of asthma exacerbations in elderly adults: results of a 1-year prospective study. J Am Geriatr Soc 2013;61:1631-2.

74. Krauskopf KA, Sofianou A, Goel MS, Wolf MS, Wilson EA, Martynenko ME, et al. Depressive symptoms, low adherence, and poor asthma outcomes in the elderly. J Asthma 2013;50:260-6.

75. Bellia V, Pedone C, Catalano F, Zito A, Davì E, Palange S, et al. Asthma in the elderly: mortality rate and associated risk factors for mortality. Chest 2007;132:1175-82.

76. Gibson PG, McDonald VM, Marks GB. Asthma in older adults. Lancet 2010;376:803-13.

77. Teodorescu M, Polomis DA, Gangnon RE, Fedie JE, Consens FB, Chervin $\mathrm{RD}$, et al. Asthma control and its relationship with obstructive sleep apnea (OSA) in older adults. Sleep Disord 2013; 2013:251567.

78. Hwang EK, Jin HJ, Nam YH, Shin YS, Ye YM, Nahm DH, et al. The predictors of poorly controlled asthma in elderly. Allergy Asthma Immunol Res 2012;4:270-6.

79. Lohia S, Schlosser RJ, Soler ZM. Impact of intranasal corticosteroids on asthma outcomes in allergic rhinitis: a meta-analysis. Allergy 2013;68:569-79.

80. American Lung Association-Asthma Clinical Research Centers' Writing Committee; Dixon AE, Castro M, Cohen RI, Gerald LB, Holbrook JT, et al. Efficacy of nasal mometasone for the treatment of chronic sinonasal disease in patients with inadequately controlled asthma. J Allergy Clin Immunol. Forthcoming 2014.

81. Vashishta R, Soler ZM, Nguyen SA, Schlosser RJ. A systematic review and meta-analysis of asthma outcomes following endoscopic sinus surgery for chronic rhinosinusitis. Int Forum Allergy Rhinol 2013;3:788-94.

82. Gevaert P, Calus L, Van Zele T, Blomme K, De Ruyck N, Bauters W, et al. Omalizumab is effective in allergic and nonallergic patients with nasal polyps and asthma. J Allergy Clin Immunol 2013;131: 110-116.el.

83. Stenius-Aarniala B, Poussa T, Kvarnström J, Grönlund EL, Ylikahri $\mathrm{M}$, Mustajoki P. Immediate and long term effects of weight reduction in obese people with asthma: randomised controlled study. BMJ 2000;320:827-32.

84. Dias-Júnior SA, Reis M, de Carvalho-Pinto RM, Stelmach R, Halpern A, Cukier A. Effects of weight loss on asthma control in obese patients with severe asthma. Eur Respir J 2014;43:1368-77.

85. Chaudhuri R, Livingston E, McMahon AD, Lafferty J, Fraser I, Spears $\mathrm{M}$, et al. Effects of smoking cessation on lung function and airway inflammation in smokers with asthma. Am J Respir Crit Care Med 2006;174:127-33.

86. Tønnesen P, Pisinger C, Hvidberg S, Wennike P, Bremann L, Westin
A, et al. Effects of smoking cessation and reduction in asthmatics. Nicotine Tob Res 2005; 7:139-48.

87. Baraniak A, Sheffield D. The efficacy of psychologically based interventions to improve anxiety, depression and quality of life in COPD: a systematic review and meta-analysis. Patient Educ Couns 2011;83:29-36.

88. Yorke J, Fleming SL, Shuldham CM. Psychological interventions for adults with asthma. Cochrane Database Syst Rev 2006:CD002982.

89. Matsunaga K, Yamagata T, Minakata Y, Ichinose M. Importance of assistance by caregivers for inhaled corticosteroid therapy in elderly patients with asthma. J Am Geriatr Soc 2006;54:1626-7.

90. Baptist AP, Talreja N, Clark NM. Asthma education for older adults: results from the National Asthma Survey. J Asthma 2011;48:133-8.

91. Sofianou A, Martynenko M, Wolf MS, Wisnivesky JP, Krauskopf K, Wilson EA, et al. Asthma beliefs are associated with medication adherence in older asthmatics. J Gen Intern Med 2013;28:67-73.

92. Federman AD, Wolf M, Sofianou A, Wilson EA, Martynenko M, Halm EA, et al. The association of health literacy with illness and medication beliefs among older adults with asthma. Patient Educ Couns 2013;92:273-8.

93. Federman AD, Wolf MS, Sofianou A, Martynenko M, O'Connor R, Halm EA, et al. Self-management behaviors in older adults with asthma: associations with health literacy. J Am Geriatr Soc 2014; 62:872-9.

94. O'Conor R, Wolf MS, Smith SG, Martynenko M, Vicencio DP, Sano $\mathrm{M}$, et al. Health literacy, cognitive function, proper use and adherence to inhaled asthma controller medications among older adults with asthma. Chest. Forthcoming 2014.

95. Baptist AP, Ross JA, Yang Y, Song PX, Clark NM. A randomized controlled trial of a self-regulation intervention for older adults with asthma. J Am Geriatr Soc 2013;61:747-53.

96. Hong JS, Kang HC, Kim J. Continuity of care for elderly patients with diabetes mellitus, hypertension, asthma, and chronic obstructive pulmonary disease in Korea. J Korean Med Sci 2010;25:1259-71.

97. Park SY, Yoon SY, Shin B, Kwon HS, Kim TB, Moon HB, et al. Clinical factors affecting discrepant correlation between asthma control test score and pulmonary function. Allergy Asthma Immunol Res 2015;7:83-7.

98. Sim DW, Choi IS, Kim SH. Suppressive effects of long-term treatment with inhaled steroids on hypothalamic-pituitary-adrenal axis in asthma. Allergy Asthma Respir Dis 2014;2:285-92.

99. Park HW. The role of tiotropium in the management of asthma. Asia Pac Allergy 2012;2:109-14.

100. Creticos P, Knobil K, Edwards LD, Rickard KA, Dorinsky P. Loss of response to treatment with leukotriene receptor antagonists but not inhaled corticosteroids in patients over 50 years of age. Ann Allergy Asthma Immunol 2002;88:401-9. 